EXPERIMENTAL PAPER

\title{
Effect of flavonoids content on antioxidant activity of commercial cosmetic plant extracts
}

\author{
PAULINA MALINOWSKA
}

Department of Technology and Instrumental Analysis

Poznan University of Economics

Al. Niepodległości 10

61-875 Poznań, Poland

e-mail: paulina.malinowska@ue.poznan.pl, phone: +4861 8569054

\section{Su m m a ry}

The aim of this work was to evaluate the antioxidant capacity and flavonoids content in 10 commercial cosmetic plant extracts used in cosmetics industry. Antioxidant activity of plant extracts were measured using two methods: FRAP (Ferric Reducing Antioxidant Power) and TEAC (Trolox Equivalent Antioxidant Capacity). The relationship between flavonoids content and antioxidant capacity of plant extracts were checked. As a result of this research it was found that FRAP and TEAC values of plant extracts significantly depend on the flavonoids content. The highest antioxidant activity, both in FRAP and TEAC assays, was observed for arnica flowers, hawthorn flowers and lungwort herb extracts. These extracts can be used as source of natural antioxidants for the prolongation of the oxidative stability of cosmetic products. Additionally, they can replace synthetic antioxidants.

Key words: plant extracts, antioxidant activity, FRAP, TEAC, cosmetics

\section{INTRODUCTION}

Flavonoids are a group of polyphenolic compounds broadly distributed as a secondary metabolites in plant kingdom. Due to their reported biological activity, flavonoids are interesting for pharmaceutical, cosmetic and food industry [1].

Botanical extracts are often rich in flavonoids which applications in cosmetology, pharmacology and food supplements have been well developed recently. In 
most publications first priority is given to the antioxidant properties of these compounds, although, it is more and more evident that flavonoids have also significant role in topically applied products. Many flavonoids can act as cofactors of all kinds of enzymes. They are also used in anti-aging, anti-cellulite, anti-couperose and skin-lightening products. Other important forms of activity of flavonoids are: strengthening of capillaries, anti-inflammatory effect, protective against radiation, moistening, softening, soothing, antiseptic and other [26]. Scientifically proven skin benefits of flavonoids and other polyphenols as cosmetic ingredients refer, for example, to prevention of the lipid oxidation [3], stimulation of fibroblast proliferation [7], reduction of collagen breakdown [8] or $5 a$-reductase [9].

Antioxidant activity is one of the most important properties of plant extracts, because scientists have looked for the sources of natural antioxidants which can replace synthetic ones in many cosmetic, pharmaceutical and food formulations. In search of novel sources of antioxidants in the past, medicinal plants have been extensively studied.

This work is aimed at a preliminary screening of antioxidant activity of extracts isolated from plants used in cosmetics industry. It was decided to conduct the analysis of extracts that have healing properties, and simultaneously they are applied in many known cosmetics, such as: Arnica montana, Crataegus monogyna, Pulmonaria officinalis, Helichrysum italicum, Sophora japonica, Arctium lappa, Polygonum aviculare, Centella asiatica, Melilotus officinalis and Hippophae rhamnoides. Moreover, listed plants exhibit stronger or weaker antioxidant activity. There are some data in the literature concerning the antioxidant properties of these medicinal plants. There is a lot of information on antioxidant properties of Arnica montana, Sophora japonica, Crataegus monogyna, Hippophae rhamnoides, and less data on antioxidant properties of Pulmonaria officinalis, Helichrysum italicum, Arctium lappa, Polygonum aviculare, Centella asiatica and Melilotus officinalis.

Independent studies have shown that Arnica montana showed a good free radical scavenging activity and cytoprotective effect against oxidative damage in fibroblast-like cells [10-12]. Extracts of Crataegus monogyna have been found to be cytoprotective by scavenging superoxide anion, hydroxyl radical, hydrogen peroxides and reducing lipid peroxidation as compared to standards such as BHA and $\alpha$-tocopherol [13-16]. Moreover, literature provides data indicating that Pulmonaria officinalis may have antioxidant effects on bacteria simultaneously through several different pathways, including direct inhibition of reactive oxygen species, iron chelation and antioxidant genes induction $[17,18]$. In previous studies, it turned out that Helichrysum italicum inhibited enzymatic and non-enzymatic lipid peroxidation and has free-radical scavenging properties [19, 20]. In turn Sophora japonica, known as anti-tyrosinase extract, was especially potent in HEMn cells in terms of free radical scavenging effects [21, 22]. There are also scientific reports indicating that Arctium lappa extracts are the strong free radical 
scavengers and exhibit selective antiproliferative activity [23-25]. Medicinal uses of burdock in treating chronic diseases such as cancers and diabetes have been reported [26]. Scientific literature provides also data indicating that Polygonum aviculare showed a good superoxide and hydroxyl radical scavenging activities [27]. The extract of Centella asiatica possesses confirmed antioxidant, cognitiveenhancing, antiepileptic, antinociceptive and anti-inflammatory properties [28, 29]. Free radical scavenging activity of Melilotus officinalis was confirmed in ORAC (Oxygen radical absorbance capacity) [30]. In turn Hippophae rhamnoides has the ability to scavenge peroxyl radicals and to protect against UV radiation. Studies indicated that it is a safe and effective antioxidant nutraceutical product [31].

The aim of this work was to determine and compare the content of flavonoids and the antioxidant capacity of 10 abovementioned plant extracts which are used in commercially available cosmetic products. In order to evaluate total antioxidant activity of these extracts two tests: Ferric Reducing Antioxidant Power (FRAP) assay and Trolox Equivalent Antioxidant Capacity (TEAC) method were chosen. Moreover the relationship between flavonoids content and the antioxidant capacity of the plant extracts were determined.

\section{MATERIAL AND METHODS}

\section{Chemicals}

The following chemicals: Trolox ${ }^{\infty}$ (6-hydroxy-2,5,7,8-tetramethylchroman-2carboxylic acid, Sigma Chemicals), TPTZ (2,4,6-tripyridyl-s-triazine, Fluka), ABTS (2,2'-azino-bis(3-ethyl-benzthiazoline-6-sulphonic acid, Roche Diagnostics), potassium persulphate, chloride aluminium hexahydrate, sodium nitrate(V), sodium hydroxide (Merck), ferric(III) chloride hexahydrate and ferric(II) sulphate heptahydrate (POCH S.A.), ethanol, methanol, acetic acid, sodium acetate trihydrate and hydrochloric acid (Chempur) were used as supplied without any purification before use. All chemicals used in this work were of analytical grade.

\section{Plant material}

Ten glycolic, hydroglycolic and/or hydroethanolic commercial cosmetic plants extracts (table 1) were obtained from two cosmetics companies: L'Angelica (Italy) and Ennagram (France). They were stored at room temperature in the dark. For the determination of flavonoids, extracts were diluted 5, 10 and 20 times; for the determination of total antioxidant capacity - 5, 10, 20, 50, 100, 200, 500 times. All dilutions of plant extracts were prepared in methanol. 
The characteristics of plant extracts used in the study

\begin{tabular}{|c|c|c|c|}
\hline $\begin{array}{l}\text { Common name } \\
\text { of plant }\end{array}$ & Latin name of plant & $\begin{array}{l}\text { Part of plant } \\
\text { Solvent }\end{array}$ & $\begin{array}{l}\text { Flavonoids naturally } \\
\text { occurring in the plant }\end{array}$ \\
\hline Arnica & Arnica montana $\mathrm{L}$. & $\begin{array}{l}\text { flowers } \\
\quad G\end{array}$ & $\begin{array}{c}\text { astragalin, luteolin, kaempferol, quercetin, } \\
\text { isoquercetrin, hispidulin, apigenin, isorhamnetin, } \\
\text { patuletin, spinacetin }[32,33]\end{array}$ \\
\hline Hawthorn & Crataegus monogyna $\mathrm{L}$. & $\begin{array}{l}\text { flowers } \\
\text { WG }\end{array}$ & $\begin{array}{l}\text { kaempferol, quercetin, rutin, } \\
\text { vitexin, hyperoside, orientin, vicenin }[32,34]\end{array}$ \\
\hline Lungwort & Pulmonaria officinalis $\mathrm{L}$. & $\begin{array}{l}\text { herb } \\
\text { G }\end{array}$ & quercetin, kaempferol [35] \\
\hline Catkin & Helichrysum italicum L. & $\begin{array}{l}\text { flowers } \\
\text { WG }\end{array}$ & $\begin{array}{l}\text { kaempferol, apigenin, } \\
\text { naringenin, luteolin [36] }\end{array}$ \\
\hline $\begin{array}{l}\text { Japanese } \\
\text { Pagoda Tree }\end{array}$ & Sophora japonica L. & $\begin{array}{l}\text { buds } \\
\text { WG }\end{array}$ & rutin, quercetin, kaempferol [37] \\
\hline Burdock & Arctium lappa $\mathrm{L}$. & root & isoquercetrin, rutin, kaempferol, quercetin [37] \\
\hline Knot-grass & Polygonum aviculare $\mathrm{L}$. & $\begin{array}{l}\text { herb } \\
\text { WE }\end{array}$ & $\begin{array}{l}\text { quercitin, hyperoside, avicularin } \\
\text { vitexin, kaempferol, miricetin [32, 34, 37] }\end{array}$ \\
\hline Gotu-kola & Centella asiatica $\mathrm{L}$. & $\begin{array}{l}\text { herb } \\
\text { G }\end{array}$ & $\begin{array}{l}\text { kaempferol, quercetin , rutin, apigenin, naringin } \\
\text { castilliferol, castillicetin }[38,39]\end{array}$ \\
\hline Sweet clover & Melilotus officinalis L. & $\begin{array}{l}\text { herb } \\
\text { WE }\end{array}$ & kaempferol, quercetin $[34,40]$ \\
\hline Buckthorn & Hippophae rhamnoides $\mathrm{L}$. & $\begin{array}{l}\text { fruit } \\
\text { WE }\end{array}$ & $\begin{array}{l}\text { quercetin, isorhamnetin, kaempferol, miricetin } \\
\qquad[41,42]\end{array}$ \\
\hline
\end{tabular}

Symbols used for solvents: W - water, E - ethanol, G - propylene glycol

\section{Flavonoids content}

The amount of flavonoids in plant extracts was determined according to Karadeniz procedure [43] using (-)epicatechin as a standard. One milliliter of extract was placed in a $10 \mathrm{ml}$ volumetric flask, and $5 \mathrm{ml}$ of distilled water and $0.3 \mathrm{ml}$ of $5 \% \mathrm{NaNO}_{2}$ were added and mixed. After 5 min, $0.6 \mathrm{ml}$ of $10 \% \mathrm{AlCl}_{3} \cdot 6 \mathrm{H}_{2} \mathrm{O}$ was added. Two milliliters of $1 \mathrm{M} \mathrm{NaOH}$ were added 5 min later and then the volume was made up to $10 \mathrm{ml}$ with distilled water. The solution was mixed well and the absorbance was measured immediately at $510 \mathrm{~nm}$. Flavonoid contents were calculated using a standard calibration curve, prepared using (-)epicatechin (fig. 1). The resulting values were expressed in $\mathrm{mg}$ epicatechin per gram of extract [mg ECE/g of extract]. Data are presented as mean \pm SD of three replicates. 


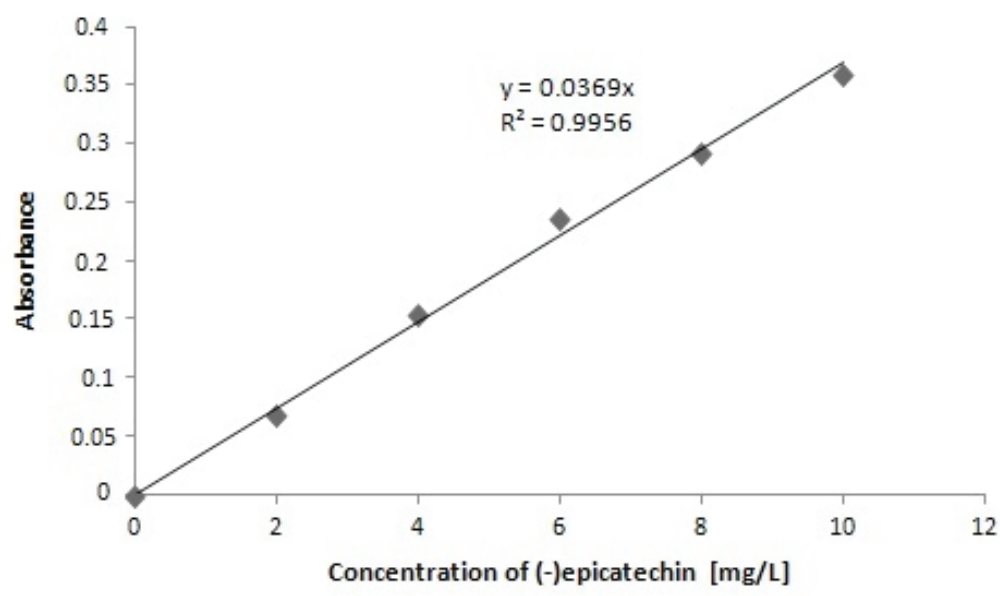

Figure 1.

Calibration curve for determination of flavonoids content in plant extracts

\section{FRAP (Ferric Reducing Antioxidant Power) assay}

The reduction power of plant extracts was measured according to the procedure described by Benzie and Strain [44]. The method is based on the reduction of $\mathrm{Fe}^{3+}$ - TPTZ (2,4,6-tripyridyl-s-triazine) complex (FRAP reagent) to the ferrous $\left(\mathrm{Fe}^{2+}\right)$ form. The appearance of a blue colour of the solution with an absorption maximum located at $593 \mathrm{~nm}$ is observed. Briefly, the FRAP reagent was prepared by mixing $25 \mathrm{ml}$ of $300 \mathrm{mM}$ acetate buffer (pH 3.6), $2.5 \mathrm{ml}$ of $10 \mathrm{mM}$ TPTZ solution in $40 \mathrm{mM} \mathrm{HCl}$ and $2.5 \mathrm{ml}$ of $20 \mathrm{mM} \mathrm{FeCl}_{3}$. For determination $30 \mu \mathrm{l}$ of various dilutions of plant extract or standard were added to $2970 \mu \mathrm{l}$ of FRAP reagent and mixed. After keeping at a room temperature for $4 \mathrm{~min}$, the increase in absorbance was measured at $593 \mathrm{~nm}$ using UV-VIS spectrophotometer Genesis 2 (Milton-Roy, USA). $\mathrm{FeSO}_{4} \cdot 7 \mathrm{H}_{2} \mathrm{O}$ was used as a standard. The measurements of antioxidant capacity by means of FRAP assay were repeated three times for each concentration of the plant extract. FRAP value was expressed in $\mu$ mol ferrous $\left(\mathrm{Fe}^{2+}\right)$ form per gram of extract $\left[\mu \mathrm{mol} \mathrm{Fe}{ }^{2+} / \mathrm{g}\right.$ extract $]$. Data are presented as mean $\pm \mathrm{SD}$ of three replicates.

\section{TEAC (Trolox Equivalent Antioxidant Capacity) assay}

Antioxidant capacity of plant extracts was measured according to the procedure described by Re et al. [45]. The method is based on the ability of antioxidant molecules to quench the long-lived $\mathrm{ABTS}^{+}$, a blue-green chromophore 
having a characteristic absorption band at $734 \mathrm{~nm}$. Before proper determination, ABTS radical cation $\left(\mathrm{ABTS}^{+}\right.$) was produced by mixing $0.2 \mathrm{ml} 24.5 \mathrm{mM}$ potassium persulphate with $7.7 \mathrm{mg}$ ABTS and $1.8 \mathrm{ml}$ redistilled water. Final concentrations were: for ABTS $-7 \mathrm{mM}$, for potassium persulphate $-2.45 \mathrm{mM}$. This solution was kept in the dark at a room temperature for 14-16 h before use. Prior to determination, this solution was diluted with methanol to obtain the solution with the absorbance of $0.7-0.8$ measured at $734 \mathrm{~nm}$. Briefly, $792 \mu \mathrm{l}$ of $\mathrm{ABTS}^{++}$solution was placed in a $1 \mathrm{~cm}$ glass cuvette and the absorbance was measured at $734 \mathrm{~nm}$, using UV-VIS spectrophotometer Genesis 2 (Milton-Roy, USA). Next $8 \mu \mathrm{l}$ of different dilutions of plant extract or standard were added to $\mathrm{ABTS}^{+}$solution and mixed. After keeping the reaction mixture at room temperature for 6 min the absorbance was measured again at $734 \mathrm{~nm}$. The measurements of antioxidant capacity by means of TEAC assay were repeated three times for each concentration of the plant extract. In all measurements Trolox was used as a standard. The resulting TEAC values were expressed in $\mu \mathrm{mol}$ Trolox per gram of extract [ $\mu \mathrm{mol}$ Trolox/g of extract]. Data are presented as mean \pm SD of three replicates.

\section{Statistical analysis}

All analyses were performed in triplicate. The recorded results were subjected to statistical analysis using SPSS Statistics 14.0 software. The results were interpreted at the significance level $p=0.05$.

\section{RESULTS AND DISCUSSION}

The content of flavonoids and the antioxidant activity of 10 plant extracts measured using FRAP and TEAC methods are presented in table 2. The amount of flavonoids varied widely in plant extracts tested and ranged from $0.16 \mathrm{mg}$ ECE/g in buckthorn fruit extract to $2.15 \mathrm{mg}$ ECE/g in arnica flowers extract. The plant extracts with the highest level of flavonoids were arnica flowers, hawthorn flowers, lungwort herb and catkin flowers extracts. Flavonoids content in these extracts were in several cases higher than in gotu-kola herb, sweet clover herb and buckthorn fruits extracts.

Similarly as observed for flavonoids content, FRAP values varied widely for plant extracts tested - they ranged from $3.68\left[\mu \mathrm{mol} \mathrm{Fe}{ }^{2+} / \mathrm{g}\right.$ of extract $]$ in gotu-kola herb extract to $32.22\left[\mu \mathrm{mol} \mathrm{Fe}{ }^{2+} / \mathrm{g}\right.$ of extract $]$ in arnica flowers extract, respectively (tab. 2). The glycolic extract of arnica flowers contained the highest flavonoids amount. It also exhibited the highest reducing potential among all extracts. It was observed that the most effective reducing extracts such as arnica flowers, 
hawthorn flowers and lungwort herb extracts had several times higher reducing potential than gotu-kola herb, sweet clover herb and buckthorn fruits extracts. The order of reducing potential of plant extracts was as follows: arnica flower $>$ lungwort herb $>$ hawthorn flower $>$ catkin flower $>$ knot-grass herb $>$ Japanese pagoda tree buds $>$ burdock root $>$ buckthorn fruit $>$ sweet clover herb $>$ gotukola herb.

Table 2 .

Flavonoids content and antioxidant capacity of 10 commercial cosmetic plant extracts

\begin{tabular}{lccc}
\hline Common name of plant & $\begin{array}{c}\text { Flavonoids } \\
{[\mathrm{mg} \text { ECE } / \mathrm{g} \text { of extract }]}\end{array}$ & $\begin{array}{c}\text { FRAP } \\
{\left[\mu \mathrm{mol} \mathrm{Fe}^{2+} / \mathrm{g} \text { of extract }\right]}\end{array}$ & $\begin{array}{c}\text { TEAC } \\
{[\mu \mathrm{mol} \text { Trolox } / \mathrm{g} \text { of extract }]}\end{array}$ \\
\hline Arnica & $2.15 \pm 0.09^{\mathrm{a}}$ & $32.22 \pm 2.10^{\mathrm{a}}$ & $20.53 \pm 1.48^{\mathrm{a}}$ \\
\hline Hawthorn & $1.70 \pm 0.05^{\mathrm{b}}$ & $16.36 \pm 0.56^{\mathrm{b}}$ & $18.23 \pm 0.34^{\mathrm{a}}$ \\
\hline Lungwort & $1.34 \pm 0.03^{\mathrm{c}}$ & $16.61 \pm 0.19^{\mathrm{b}}$ & $10.41 \pm 0.34^{\mathrm{b}}$ \\
\hline Catkin & $1.02 \pm 0.05^{\mathrm{d}}$ & $11.78 \pm 0.09^{\mathrm{c}}$ & $10.51 \pm 0.36^{\mathrm{b}}$ \\
\hline Japanese Pagoda Tree & $0.65 \pm 0.02^{\mathrm{e}}$ & $10.42 \pm 0.11^{\mathrm{d}}$ & $10.76 \pm 1.22^{\mathrm{b}}$ \\
\hline Burdock & $0.62 \pm 0.01^{\mathrm{e}}$ & $6.95 \pm 0.17^{\mathrm{f}}$ & $4.91 \pm 0.44^{\mathrm{d}}$ \\
\hline Knot-grass & $0.54 \pm 0.01^{\mathrm{f}}$ & $10.51 \pm 0.32^{\mathrm{d}}$ & $11.69 \pm 0.42^{\mathrm{b}}$ \\
\hline Gotu-kola & $0.33 \pm 0.03^{\mathrm{g}}$ & $3.68 \pm 0.33^{\mathrm{h}}$ & $2.28 \pm 0.24^{\mathrm{f}}$ \\
\hline Sweet clover & $0.27 \pm 0.02^{\mathrm{g}}$ & $5.88 \pm 0.23^{\mathrm{g}}$ & $6.82 \pm 0.25^{\mathrm{c}}$ \\
\hline Buckthorn & $0.16 \pm 0.01^{\mathrm{h}}$ & $6.20 \pm 0.11^{\mathrm{e}}$ & $3.02 \pm 0.15^{\mathrm{e}}$ \\
\hline
\end{tabular}

${ }^{1} \mathrm{ECE}-(-)$ epicatechin

Values (mean $\pm \mathrm{SD}$ ) are average of three independent experiments.

$\mathrm{a}, \mathrm{b}, \mathrm{c} . . .-$ mean with different letters in columns are statistically different at $\mathrm{p} \leq 0.05$.

A positive correlation between FRAP values and the flavonoids content in 10 plant extracts was found $(r=0.931 ; p \leq 0.05$, fig. 2$)$. The reliable correlation obtained indicates that the reducing power (FRAP) of plant extracts depends on their flavonoids content significantly.

Similarly as observed for FRAP, TEAC values obtained in the TEAC method, respectively (tab. 2) varied widely for plant extracts tested - they ranged from 2.28 $[\mu \mathrm{mol}$ Trolox/g of extract] in gotu-kola herb extract to $20.53[\mu \mathrm{mol}$ Trolox $/ \mathrm{g}$ of extract] in arnica flowers extract. The highest TEAC values were observed for arnica flowers, hawthorn flowers and knot-grass herb extracts, which also contained the highest amount of flavonoids. The lowest TEAC values were obtained for gotukola herb, buckthorn fruits and burdock root extracts. The order of antioxidant capacity of plant extracts was as follows: arnica flower $>$ hawthorn flower $>$ knotgrass herb $>$ Japanese pagoda tree buds $>$ catkin flower $>$ lungwort herb $>$ sweet clover herb $>$ burdock root $>$ buckthorn fruit $>$ gotu-kola herb. 


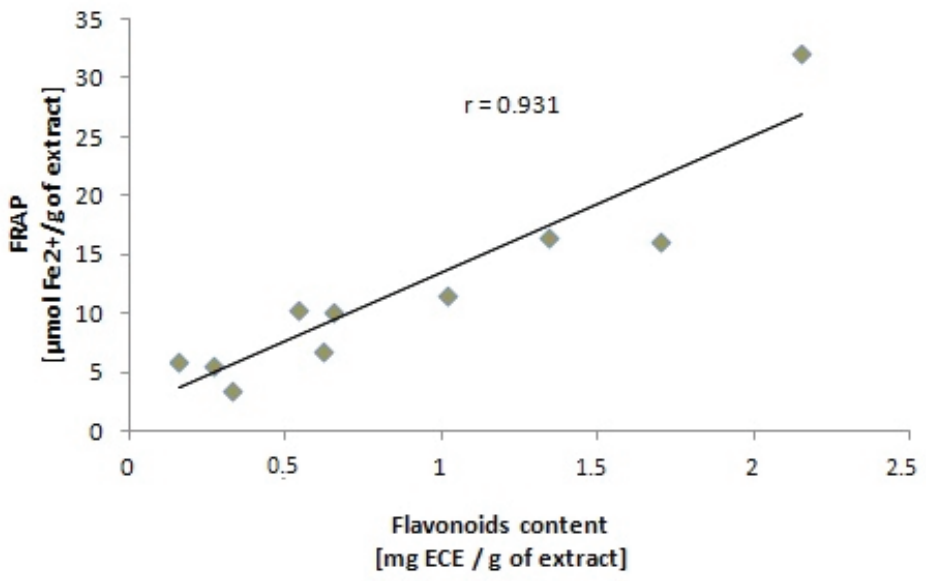

Figure 2 .

The relationship between flavonoids content and FRAP values found for plant extracts $(r=0.931$; $p \leq 0.05)$

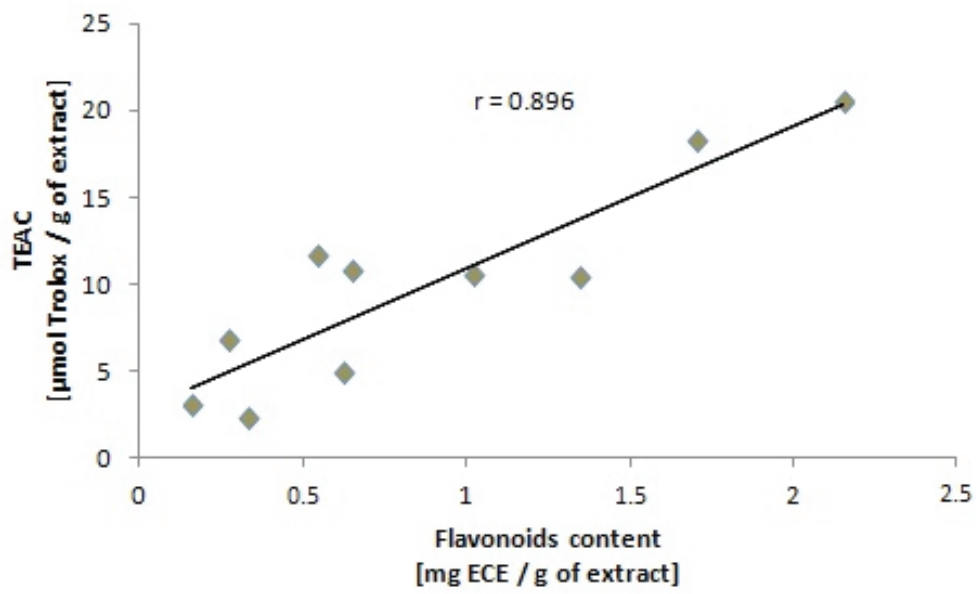

Figure 3.

The relationship between flavonoids content and TEAC values found for plant extracts $(r=0.896$; $p \leq 0.05)$

Obtained high correlation between TEAC values and flavonoids content in plant extracts $(\mathrm{r}=0.896 ; p \leq 0.05$, fig. 3$)$ again indicates that flavonoids are the main antioxidants in researched plant extracts.

On the basis of these results it can be concluded that the higher value of antioxidant activity of plant extract is related to their higher flavonoids content. From the obtained high correlations between flavonoids content and the antioxidant 
capacity of plant extracts it may be deduced that we may approximately estimate flavonoids content in researched plant extracts using FRAP and TEAC assays.

Moreover, on the basis of this research commercial plant extracts with the highest antioxidant activity: arnica flowers, hawthorn flowers and lungwort herb extracts can be proposed as a good source of natural antioxidants for cosmetic and pharmaceutical topical formulations.

Regardless from the antioxidant activity, these plant extracts have many other properties, so they can be applied in many kinds of cosmetics (tab. 3). Recently, arnica has become popular as topical treatment in gel or cream form to reduce inflammatory skin conditions, bruising and heal chronic wounds [46]. Literature provides data indicating that it is more popular cosmetic ingredient than hawthorn and lungwort [47], but due to the growth of "natural trend" in cosmetics, the interest in natural resources is growing as well. Therefore, cosmetologists have become interested in plant extracts which were not applied before.

Table 3 .

Commercial plant extracts with the highest antioxidant activity - cosmetic properties and the application in cosmetic formulations

\begin{tabular}{|c|c|c|}
\hline $\begin{array}{l}\text { Plant } \\
\text { extract }\end{array}$ & Properties & $\begin{array}{c}\text { Application of plant extracts by cosmetic } \\
\text { producers [48] }\end{array}$ \\
\hline Arnica & $\begin{array}{l}\text { - regenerating - reducing flaking and restoring } \\
\text { suppleness }[49,50] \\
\text { - sealing capillary vessels [50,51] } \\
\text { - anti-reddening [51] } \\
\text { - anti-swelling [50,52, 53, 54] } \\
\text { - anti-inflammatory [50, 52, 55] } \\
\text { - antimicrobial [56] } \\
\text { - astringent [57] } \\
\text { - soothing [57] } \\
\text { - antiseptic [51] } \\
\text { - UV protective [58] } \\
\text { - stimulate the hair follicles [51] }\end{array}$ & $\begin{array}{l}\text { - anti-couperose products } \\
\text { - anti-inflammatory and regenerating } \\
\text { cosmetics } \\
\text { - stimulating shampoos } \\
\text { - shower and bath gels } \\
\text { - foot care cosmetics } \\
\text { - deodorants }\end{array}$ \\
\hline Hawthorn & $\begin{array}{l}\text { - anti-irritant [59] } \\
\text { - anti-inflammatory [60] } \\
\text { - anti-couperose [59] } \\
\text { - anti-itching [51] } \\
\text { - UV protective [60] } \\
\text { - skin and hair regenerating and stimulating } \\
\text { [61,62] }\end{array}$ & $\begin{array}{l}\text { - sensitive skin care products } \\
\text { - shampoos and conditioners for dry, } \\
\text { damaged hair } \\
\text { - anti - dandruff shampoos and conditioners } \\
\text { - relaxing shower and bath gels }\end{array}$ \\
\hline Lungwort & $\begin{array}{l}\text { - regenerating }[62,63] \\
\text { - anti-irritant }[50] \\
\text { - anti-inflammatory }[62,63] \\
\text { - anti-bacterial }[62,63]\end{array}$ & $\begin{array}{l}\text { - anti-acne products } \\
\text { - oily and sensitive skin care cosmetics } \\
\text { - regenerating products }\end{array}$ \\
\hline
\end{tabular}

These plant extracts can be a good solution for anti-allergic cosmetics, which are made of only a few compounds in order to avoid allergy. In these cosmetics 
only one plant extract can be used instead of few synthetic compounds, but care effect will be the same.

Nowadays, a few hundreds of plant extracts with various flavonoids content, different antioxidant activity and simultaneously various quality are available on Polish cosmetics market. In the research conducted it was found that some plant extracts known generally for high flavonoids or ascorbic acid content, such as buckthorn fruits extract, in this work showed very low antioxidant activity. Similarly extracts from exotic plants, such as Japanese Pagoda Tree buds or gotu-kola herb, also revealed relatively low antioxidant activity. The reason may be the quality of the available commercial cosmetic plant extracts. The problem can be bound with low quality of some of them. It is supposed that it can be caused by extraction method of active ingredients from the plant raw material or by excessive dilution of the extracts by their producers.

\section{CONCLUSION}

Commercial cosmetic plant extracts are available and used in cosmetic: industry, however, their flavonoids content and the antioxidant capacity vary among different extracts significantly.

As a result of this research it was found that antioxidant capacity of plant extracts is significantly affected by their flavonoids content. The highest antioxidant activity, both in FRAP and TEAC assays, was observed for: arnica flowers, hawthorn flowers and spotty bugloss herb extracts. They can be used as natural antioxidants for prolonging the stability of cosmetic products and replace synthetic antioxidants such as BHT or BHA, which can cause skin allergy.

In this work, it was turned out that FRAP and TEAC methods can be effective and credible tests for evaluation the antioxidant activity of commercial plant extracts used in cosmetics industry. FRAP and TEAC values are sufficiently good parameters to assess the quality of plant extracts used in cosmetics industry, in relation to their flavonoids content. These methods could be successfully applied for quick, preliminary quality evaluation of plant extracts. It is very important, as the quality of cosmetics depends on the quality of their active ingredients.

\section{REFERENCES}

1. Rolim A, Oishi T, Maciel C, Zague V, Pinto C, Kaneko TM, Consiglieri VO, Velasco MVR. Total flavonoids quantification from O/W emulsion with extract of Brazilian plants. Int J Pharmaceutics 2005; 308 (1-2):107114.

2. Prakash L, Satyan KS, Mejeed S. Multifunctional ingredients: The novel face of natural. Cosmet Toil 2003; 118 (11):41-45.

3. Brand-Garnys EE, Van Dansik P, Brand HM. Looking in the face of cosmeceuticals. SÖFW Journal 2001; $127(1 / 2): 8-13$. 
4. Katiyar SK, Ahmad N, Mukhtar H. Green tea and skin. Arch Dermatol 2000; 136:989-994.

5. Schmid D, Zulli F, Nissen HP, Prieur H. Penetration and metabolism of isoflavones in human skin. Cosmet Toil 2003; 118 (9):71-76.

6. Svobodova A, Psotova I, Walterova D. Natural phenolics in the prevention of UV-induced skin damage. A review. Biomed Papers 2003; 147 (2):137-145.

7. Kim SJ, Lim MH, Chun IK, Won YH. Effects of flavonoids of Ginkgo biloba on proliferation of human skin fibroblast. Skin Pharmacol 1997; 10 (4):200-205.

8. Schmid D, Zulli F. Topically applied soy isoflavones increase skin thickness. Cosmet Toil 2002; 117 (6):45-50.

9. Hiipakka RA, Zhang HZ, Dai W, Dai Q, Liao S. Structure-activity relationships for inhibition of human 5a-reductases by polyphenols. Biochem Pharmacol 2002; 63 (6):1165-1176.

10. Craciunescu O, Constantin D, Gaspar A, Toma L, Utoiu E, Moldovan L. Evaluation of antioxidant and cytoprotective activities of Arnica montana L. and Artemisia absinthium L. ethanolic extracts. Chemistry Central Journal 2012; 97:1-11.

11. Kokate CK, Purohit AP. Textbook of pharmacognosy, 2004; 29:317.

12. Ganzera M, Egger $\mathrm{CH}$, Zidorn $\mathrm{CH}$, Stuppner H. Quantitative analysis of flavaonoids and phenolic acids in Arnica montana L. by micellar electrokinetic capillary chromatography. Analytica Chimica Acta 2008; 614:196-200.

13. Bahorun T, Trotin F, Pommery J, Vasseur J, Pinkas M. Antioxidant activities of Crataegus monogyna extracts. Planta Medica 1994; 60 (4):323-328.

14. Rice-Evans C. Flavonoids and isoflavones: absorption, metabolism and bioactivity. Free Radic Biol Med 2004; 36 (7): 827-828.

15. Bahorun T, Gressier B, Trotin F. Oxygen species scavenging activity of phenolic extracts from hawthorn fresh plant organs and pharmaceutical preparations. Arzneimittel-Forschung 1996; 46 (11):1086-1089.

16. Keser S, Celik S, Turkoglu S, Yilmaz Ö, Turkoglu I. Hydrogen peroxide radical scavenging and total antioxidant activity of Hawthorn. Chem J 2012; 2 (1):9-12.

17. Ivanova D, Gerova D, Chervenkov T, Yankova T. Polyphenols and antioxidant capacity of Bulgarian medicinal plants. J Ethnopharmacol 2005; 96 (1-2):145-150.

18. Oktyabrsky O, Vysochina G, Muzyka N. Assessment of anti-oxidant activity of plant extracts using microbial test systems, J Appl Microbiol 2009; 106 (4):1175-1183.

19. Sala A, Recio M, Giner RM, Má $\square$ ez S, Tournier H, Schinella G, Ríos J-L. Anti-inflammatory and antioxidant properties of Helichrysum italicum. J Pharm Pharmacol 2002; 54 (3):365-371.

20. Tundis R, Statti GA, Conforti F, Bianchi A, Agrimonti C, Sacchetti G, Muzzoli MM, Ballero M, Menichini F, Poli F. Influence of environmental factors on composition of volatile constituents and biological activity of Helichrysum italicum (Roth) Don (Asteraceae). Nat Prod Res 2005; 19 (4):379-387.

21. Wang KH, Lin RD, Hsu FL, Huang YH, Chang HC, Huang CY, Lee MH. Cosmetic applications of selected traditional Chinese herbal medicines. J Ethnopharmacol 2006; 106 (3):353-359.

22. Zhang L, Ravipati AS, Koyyalamudi SR, Jeong SC, Reddy N, Smith PT, Bartlett J, Shanmugam K, Münch G, Wu MJ. Antioxidant and anti-inflammatory activities of selected medicinal plants containing phenolic and flavonoid compounds. J Agric Food Chem 2011; 59 (23):12361-12367.

23. Predes FS, Ruiz AL, Carvalho JE, Foglio MA, Dolder H. Antioxidative and in vitro antiproliferative activity of Arctium lappa root extracts. BMC Complement Altern Med 2011; 23: 11-25.

24. Maruta Y, Kawabata J, Niki R. Antioxidative caffeoylquinic acid derivatives in the roots of burdock. J Agric Food Chem 1995; 43:2592-2595.

25. Pin-Der-Duh X. Antioxidant activity of burdock (Arctium lappa Linne): it's scavenging effect on free radical and active oxygen. J Am Oil Chem Soc. 1998; 75:455-461.

26. Chan YS, Cheng LN, Wu JH, Chan E, Kwan YW, Lee SM, Leung GP, Yu PH, Chan SW. A review of the pharmacological effects of Arctium lappa (burdock). Inflammopharmacology 2011; 19 (5):245-254.

27. Hsu CY. Antioxidant activity of extract from Polygonum aviculare L. Biol Res 2006; 39 (2):281-288.

28. Gupta YK, Veerendra Kumar MH, Srivastava AK. Effect of Centella asiatica on pentylenetetrazole-induced kindling, cognition and oxidative stress in rats. Pharmacol Biochem Behav 2003; 74:579-585.

29. Zainol MK, Abd-Hamid A, Yusof S, Muse R. Antioxidant activity and total phenolic compounds of leaf, root and petiole of four accessions of Centella asiatica (L.) urban. Food Chem 2003; 81 (4):575-591.

30. Kratchanova M, Denev P, Ciz M, Lojek A, Mihailov A. Evaluation of antioxidant activity of medicinal plants containing polyphenol compounds. Comparison of two extraction systems. Acta Biochim Pol 2010; 57 (2):229-234. 
31. Chawla R, Arora R, Singh S, Sagar RK, Sharma RK, Kumar R, Sharma A, Gupta ML, Singh S, Prasad J, Khan HA, Swaroop A, Sinha AK, Gupta AK, Tripathi RP, Ahuja PS. Radioprotective and antioxidant activity of fractionated extracts of berries of Hippophae rhamnoides. J Med Food 2007; 10 (1):101-109.

32. Kohlmünzer S. Farmakognozja, Wyd. Lekarskie PZWL Warszawa 2003.

33. Jaroniewski W. Arnika górska i jej zastosowanie w lecznictwie, Wiadomości Zielarskie, 1996, 5:5-6.

34. Matlawska I. (red). Farmakognozja. Wyd. Akademii Medycznej w Poznaniu, Poznań 2005.

35. http://www.herbworld.com (accessed at 28.03.2013).

36. Karasartov BS, Kurkin VA, Zapesochnaya GG. Coumarins and flavonoids of the flowers of Helichrysum italicum. Chem Nat Compounds 1992; 5: 504-505.

37. Cai Y, Luo Q, Sun M, Corke H. Antioxidant activity and phenolic compounds of 112 traditional Chinese medicinal plants associated with anticancer. Life Sci 2004; 74:2157-2184.

38. Subban R, Veerakumar A, Manimaran R, Hashim KM, Balachandran I. Two new flavonoids from Centella asiatica (Linn.). J Nat Med 2008; 62(3):369-373.

39. Seevaratnam V, Banumathi P, Premalatha MR, Sundaram SP, Arumugam T. Functional properties of Centella asiatica (L.): a review. Int J Pharm Pharm Sci 2012; 4:8-14.

40. Suhail AM, Mohtasheem M, Iqbal A, Ahmed SW, Bano H. Chemical constituents from Melilotus officinalis. J Basic Applied Sci 2008; 4 (2):89-94.

41. Noculak-Palczewska A, Rykowski P. Rokitnik zwyczajny Hippophae rhamnoides L. i jego zastosowanie w kosmetyce. Pol J Cosmetol 2003; 6 (1):35-43.

42. Zeb A. Important therapeutic uses of Sea Buckthorn (Hippophae): a review. J Biol Sci 2004; 4 (5):687-693.

43. Karadeniz F, Burdurlu HS, Koca N, Soyer Y. Antioxidant activity of selected fruits and vegetables grown in Turkey. Turk J Agric For 2005; 29 (4):297-303.

44. Benzie IFF, Strain JJ. The Ferric Reducing Ability of Plasma (FRAP) as a Measure of Antioxidant Power: The FRAP Assay. Anal Biochem 1996; 239:70-76

45. Re R, Pellegrini N, Proteggente A, Pannala A, Yang M, Rice-Evans C. Antioxidant activity applying improved ABTS radical cation declorization assay. Free Radic Biol Med 1999; 26 (9-10):1231-1237.

46. Baumann LS. Less-known botanical cosmeceuticals. Dermatol Therapy 2007; 20:330-342.

47. Malinowska P, Szymusiak H. Plant extracts as cosmetic ingredients. Pol J Commodity Sci 2008; 2(15):33-40.

48. Technical Data Sheets of commercial plant extracts.

49. http://www.cosmeticsinfo.org (access 28.03.2013).

50. Jędrzejko K, Kowalczyk B, Bacler B. Rośliny kosmetyczne, Wyd. Śląskiej Akademii Medycznej, Katowice 2006.

51. D’Amelio FS. Botanicals: a phytocosmetic desk reference, CRC Press LLC, USA 1999.

52. Beg S, Swain S, Hasan H, Barkat MA, Hussain MS. Systematic review of herbals as potential antiinflammatory agents: Recent advances, current clinical status and future perspectives. Pharmacogn Rev. 2011; 5(10):120-137.

53. Kouzi SA, Nuzum DS, Arnica for bruising and swelling. Am J Health Syst Pharm 2007; 64(23):2434-2443.

54. Lamer-Zarawska E, Chwała C, Gwardys A. Rośliny w kosmetyce i kosmetologii, Wyd. Lekarskie PZWL Warszawa 2012.

55. Widring R, Sutter A. Chosing between NSAID and arnica for topical treatment of hand osteoarthritis in a randomized, double-blind study. Rheumatol Int 2007; 27(6):585-591.

56. Cowan MM. Plant products as antimicrobial agents. Clin Microbiol Rev 1999; 12(4):564-582.

57. Dureja H, Kaushik D, Gupta M, Kumar V, Lather V. Cosmeceuticals: an emerging concept, Indian J Pharmacol 2005; 37(3):155-159.

58. Korać RR, Khambholja KM. Potential of herbs in skin protection from ultraviolet radiation, Pharmacogn Rev 2011; 5(10):164-173.

59. http://www.mani-gmbh.com (access 28.03.2013).

60. Dumitriu B, Olariu L, Ene MD, Zglimbea L, Rosoiu N. The photo-protective activity of Crataegus monogyna extract proved by complementary mechanisms of skin inflammation, damage of extracellular matrix, cellular survival and proliferation disorders. Int J Biotechnog Wellness Industries 2012; 1:177-188.

61. http://pl.provitalgroup.com/pl (accessed 28.03.2013).

62. Czerpak R, Jabłońska-Trypuć A. Roślinne surowce kosmetyczne, Wyd. Medpharm Polska, Wrocław 2008.

63. Senderski AE. Prawie wszystko o ziołach, Wyd. Senderski, Podkowa Leśna 2004. 
WPŁYW ZAWARTOŚCI FLAWONOIDÓW NA AKTYWNOŚĆ PRZECIWUTLENIAJĄCĄ HANDLOWYCH KOSMETYCZNYCH EKSTRAKTÓW ROŚLINNYCH

\section{PAULINA MALINOWSKA}

Katedra Technologii i Analizy Instrumentalnej

Wydział Towaroznawstwa

Uniwersytet Ekonomiczny w Poznaniu

Aleja Niepodległości 10

61-875 Poznań

e-mail: paulina.malinowska@ue.poznan.pl, tel.: +4861 8569054

Streszczenie

Celem badań była ocena aktywności przeciwutleniającej i zawartości flawonoidów w 10 handlowych kosmetycznych ekstraktach roślinnych stosowanych w przemyśle kosmetycznym. Ich aktywność przeciwutleniającą zmierzono przy użyciu dwóch metod: Ferric Reducing Antioxidant Power (FRAP) i Trolox Equivalent Antioxidant Capacity (TEAC). Ponadto sprawdzono zależność między zawartością flawonoidów w ekstraktach roślinnych a ich aktywnością przeciwutleniającą. Stwierdzono, iż wartości wskaźników FRAP i TEAC wyznaczone dla ekstraktów roślinnych w sposób istotny zależą od zawartych w nich flawonoidów. Najwyższą aktywność przeciwutleniającą, zarówno w teście FRAP, jak i TEAC, zaobserwowano dla ekstraktu z arniki górskiej, głogu jednoszyjkowego i miodunki plamistej. Ekstrakty te mogą być użyte jako źródła naturalnych przeciwutleniaczy dla przedłużenia stabilności oksydacyjnej produktów kosmetycznych i ponadto mogą zastępować syntetyczne przeciwutleniacze.

Słowa kluczowe: ekstrakty roślinne, aktywność przeciwutleniająca, FRAP, TEAC, kosmetyki 